\title{
PENGARUH PERBEDAAN LABA AKUNTANSI DAN LABA FISKAL SERTA ROA TERHADAP CUMULATIVE ABNORMAL RETURN PADA PERUSAHAAN MANUFAKTUR YANG TERDAFTAR DI BURSA EFEK INDONESIA PADA TAHUN 2009
}

\author{
Indra Pahala* \\ Tresno Eka Jaya* \\ Grace Ombun Meilisa*
}

\begin{abstract}
In general, investor inculcates ithe capital into company through stock market to obtain earnings from ithe investment rate of return. On the other side, company requires fund to going concern and to do activity from investor. Therefore, company requires trust from investor through appraisal of performance coming from ROA. In reporting of income often happened difference between accounting incomes and fiscal income.

This research aim to know difference influence between accounting incomes and fiscal income and Return On Assets (ROA) to Cumulative Abnormal Return (CAR) at inscribed manufacturing business in BEI in the year 2009. This research variable is difference of accounting income and fiscal income $\left(X_{1}\right), R O A$ $\left(X_{2}\right)$ and CAR (Y). Sample total 77 companies. Data applied is financial statements and the price of stock from each company sample obtained in BEI. Analytical method applied is in this research is quantitative method with testing of classic assumption and doubled linear regression analysis. While testing of hypothesis done with determination analysis $\left(R^{2}\right)$, significance test simultan (test $F$ ) and individual parameter significance test (test $t$ ) with $a=5 \%$.

Test Result $F$ indicates that difference variable between accounting incomes and fiscal income and ROA has influence signifikan simultan to CAR. This thing is visible from output SPSS showing level of signifikansi which less than $a(0.021<0.05)$. While test result $t$ this research indicates that difference between accounting incomes and fiscal income influential positive to CAR posed at with level of signifikansi which less than a $(0010<005)$. Result of this research in line with research of Lev and Nissim (2004) that book-tax differences influential positive to return stock. In this research ROA doesn't
\end{abstract}


have an effect on to CAR posed at with level of signifikansi which more than a (0221 < 005).

This research in line with research of Sasongko and Wulandari (2005), Mukhtaruddin and Romalo (2007) and Stella (2009) in their research concluding that return on assets doesn't have an effect on to the price of stock.

Key words: Book-Tax Differences (BTD), Return On Assets (ROA), Cumulative Abnormal Return (CAR)

\section{PENDAHULUAN}

Pada umumnya, investor menanamkan modalnya ke dalam perusahaan melalui pasar modal karena ingin berinvestasi secara aman untuk memperoleh pendapatan dari tingkat pengembalian investasinya (return). Abnormal return disebabkan oleh penilaian investor yang terlalu tinggi terhadap laporan keuangan perusahaan (over estimate) sehingga harga sahamnya tidak sesuai dengan yang sebenarnya (miss pricing). Di sisi lain, perusahaan membutuhkan dana untuk mempertahankan hidupnya dan melaksanakan aktivitasnya yang dapat diperoleh dari investor. Oleh karena itu, perusahaan

\footnotetext{
* Indra Pahala, Tresno Eka Jaya, \& Grace Ombun Meilisa. Dosen Fakultas Ekonomi Universitas Negeri Jakarta.
}

membutuhkan kepercayaan dari investor melalui penilaian kinerja.

Ukuran kinerja perusahaan yang digunakan dalam penelitian ini berasal dari laba dan Return On Assets (ROA). Laba yang dilaporkan juga menjadi dasar dalam penerapan pajak. Dalam pelaporan laba sering terjadi perbedaan antara laba akuntansi dan laba fiskal. Perbedaan tersebut disebabkan laba fiskal yang dihitung berdasarkan peraturan perpajakan sedangkan laba akuntansi didasarkan pada Standar Akuntansi Keuangan (SAK). Adanya perbedaan kepentingan juga menimbulkan adanya perbedaan antara laba akuntansi dan laba fiskal dalam laporan keuangan. Pada umumnya, laporan keuangan menurut akuntansi bertujuan memberikan informasi keuangan kepada pihak-pihak yang berkepentingan dalam mengambil keputusan. Sedangkan laporan 
keuangan fiskal menunjukkan perhitungan besarnya kewajiban pajak perusahaan. Kebijakan pajak cenderung mempersempit pergerakan perusahaan untuk keperluan perhitungan pajak pendapatan. Oleh karena itu, manajemen cenderung untuk memperkecil perbedaan laba akuntansi dan laba fiskal sehingga investor dapat lebih yakin untuk menanamkan sahamnya di perusahaan tersebut yang pada akhirnya harga saham perusahaan dapat meningkat.

Laba akuntansi berasal dari laba sebelum dikurangi beban pajak sedangkan laba fiskal berasal dari laba (penghasilan) kena pajak selama satu periode. Return On Asset (ROA) berasal dari rasio antara laba bersih setelah pajak (Earnings After Tax - EAT) terhadap total aset. Laba yang mengalami kenaikan dari tahun ke tahun membuat para investor menjadi tertarik untuk menanamkan modalnya pada suatu perusahaan.

Lev dan Nissim (2004) dalam penelitiannya menyimpulkan bahwa book-tax differences berpengaruh positif terhadap return saham baik sebelum dan sesudah implementasi Statement of Financial Accounting Standards (SFAS). Desai dan
Dharmapala (2006) dalam penelitiannya yang berjudul "Corporate Tax Avoidance and HighPowered Incentives" menyimpulkan bahwa di antara penghindaran pajak dan insentif manajemen (manajemen laba) terdapat tax sheltering dan diversi manajerial. Penghindaran pajak untuk manajemen laba ini mengakibatkan tidak mencerminkan perusahaan dalam keadaan sesungguhnya karena menimbulkan adanya perbedaan laba akuntansi dan laba pajak (book-tax gap). Semakin besar perbedaan itu, maka berpengaruh negatif terhadap abnormal return.

Sasongko dan Wulandari (2005) dalam penelitiannya menyimpulkan bahwa hanya EPS yang berpengaruh terhadap harga saham sedangkan return on assets, return on equity, return on sale, basic earning power dan economic value added tidak berpengaruh terhadap harga saham. Hal ini berbeda dengan penelitian Syauta dan Widjaja (2009) dalam penelitiannya yang menyimpulkan bahwa rasio ROA memiliki pengaruh terhadap gejolak return saham perbankan.

Dengan adanya perbedaan hasil penelitian antara Lev dan 
Nissim (2004) dengan Desai dan Dharmapala (2006), membuat penulis ingin mencoba meneliti kembali pengaruh perbedaan laba akuntansi dan laba fiskal terhadap cumulative abnormal return. Selain itu, penulis tertarik untuk mengetahui pengaruh kinerja keuangan terhadap cumulative abnormal return melalui return on assets. Adanya perbedaan hasil penelitian pengaruh ROA terhadap harga saham antara Sasongko dan Wulandari (2005) dengan Syauta dan Widjaja (2009) membuat penulis ingin mencoba meneliti kembali ROA.

\section{Rumusan Masalah}

Dari latar belakang masalah seperti yang telah diuraikan sebelumnya, penulis merumuskan permasalahan sebagai berikut:

1. Apakah terdapat pengaruh perbedaan laba akuntansi dengan laba fiscal terhadap cumulative abnormal return?

2. Apakah terdapat pengaruh Return on Assets terhadap cumulative abnormal return?

\section{KAJIAN PUSTAKA \\ Pasar Modal}

Pasar modal didefinisikan oleh Katoppo et al (1997 : 1) sebagai salah satu jenis pasar di mana para pemodal bertemu untuk menjual atau membeli surat-surat berharga atau efek. Bursa Efek sebagai pasar modal di Indonesia menghasilkan indikator terhadap saham-saham perusahaan yang diperdagangkan dengan menerbitkan Indeks Harga Saham Gabungan (IHSG). Hal serupa pernah dikemukakan oleh Manurung (2009) bahwa BEI sebagai tempat para investor melakukan transaksi dan indikator bursa selalu menggunakan Indeks Harga Saham Gabungan (IHSG).

\section{Efisiensi Pasar}

Menurut Jogiyanto (2009 : 499) kondisi pasar dikatakan efisien jika pasar bereaksi dengan cepat dan akurat untuk mencapai harga keseimbangan baru yang sepenuhnya mencerminkan informasi yang tersedia.

\section{Saham}

Menurut Darmadji dan Fakhruddin (2001 : 5) mendefinisikan saham sebagai tanda penyertaan atau pemilikan seseorang atau badan dalam suatu perusahaan atau perseroan terbatas yang berwujud selembar kertas yang menerangkan bahwa pemilik kertas tersebut adalah pemilik 
perusahaan yang menerbitkan surat berharga tersebut.

\section{Return Saham}

Return merupakan tingkat pengembalian investasi yang diharapkan investor. Pada umumnya, investor akan memilih investasi yang memiliki return yang paling tinggi dengan resiko yang paling rendah.

\section{Cumulative Abnormal Return}

Return abnormal menurut Agung Suaryana (2008) menunjukkan respons pasar terhadap suatu peristiwa. Oleh karena itu, cumulative abnormal return merupakan kumulatif harian abnormal return. Dalam penelitian ini menggunakan periode 1 tahun. Untuk menghitung return ekspektasi, Brown dan Warner (dalam Michael Hendrawijaya, 2009) dapat dihitung atau diperoleh dengan menggunakan tiga model yaitu Mean-Adjusted Model, Market Model dan Market adjusted model.

\section{Laporan Keuangan Komersial dan Laporan Keuangan Fiskal}

Menurut Hidayat (2002), format dalam penyajian laporan keuangan hampir tidak memerlukan pembeda antara laporan keuangan komersial dengan laporan keuangan fiskal. Namun, menurut Hidayat apabila ditelusuri lebih dalam ada beberapa metode yang memaksa harus berbeda antara keduanya yang dapat dilihat dalam asumsi dasar pencatatan, penyajian neraca dan penyajian laporan laba rugi.

\section{Perbedaan Laba Akuntansi dan Laba Fiskal}

Dalam PSAK No. 46, laba akuntansi didefinisikan sebagai laba atau rugi selama satu periode sebelum dikurangi beban pajak. Sedangkan laba kena pajak atau laba fiskal (rugi pajak atau rugi fiskal) adalah laba (rugi) selama satu periode yang dihitung berdasarkan peraturan yang ditetapkan oleh Otoritas Pajak atas pajak penghasilan yang terutang (dilunasi).

$$
\text { Menurut Agoes dan }
$$

Trisnawati (2008) perbedaan antara laba akuntansi dan laba fiskal tersebut dapat dikelompokkan menjadi 2 yaitu:

1. Beda Tetap / Permanen

Beda tetap terjadi karena adanya perbedaan pengakuan penghasilan dan biaya menurut akuntansi dengan menurut pajak. Hal ini berarti adanya penghasilan dan biaya yang diakui menurut 
akuntansi komersial namun tidak diakui menurut fiskal. Atau sebaliknya. Beda tetap mengakibatkan laba / rugi menurut akuntansi berbeda secara tetap dengan laba kena pajak menurut fiskal. Beda tetap biasanya timbul karena peraturan perpajakan yang mengharuskan penghasilan yang telah dikenakan PPh final (Pasal 4 ayat 2 UU PPh), penghasilan yang bukan objek pajak (Pasal 4 ayat 3 UU PPh) dan pengeluaran yang tidak berhubungan langsung dengan kegiatan usaha (Pasal 9 ayat $1 \mathrm{UU}$ PPh) dikeluarkan dari perhitungan Penghasilan Kena Pajak.

\section{Beda Waktu / Sementara}

Beda waktu merupakan perbedaan perlakuan akuntansi dan perpajakan yang sifatnya temporer. Hal ini berarti secara keseluruhan beban atau pendapatan akuntansi maupun perpajakan sebenarnya sama tetapi berbeda alokasi setiap tahunnya. Beda waktu biasanya timbul karena perbedaaan metode yang dipakai antara pajak dengan akuntansi.

\section{Return On Assets (ROA)}

Prastowo dan Juliaty (2008:91) menyebutkan bahwa ROA mengukur kemampuan perusahaan dalam memanfaatkan aktivanya untuk memperoleh laba. Teori ini sejalan dengan Hartono dan Sihotang (2008) yang menyebutkan Return On Assets (ROA) merupakan rasio keuangan yang menunjukkan kemampuan perusahaan menghasilkan laba dari aktiva yang dipergunakan.

$\mathrm{ROA}=$ laba bersih setelah pajak

total aktiva

\section{Konsep Laba}

Menurut Riahi dan Belkaoui (2007: 226) mendefinisikan laba dipandang sebagai:

1. dasar untuk perpajakan dan redistribusi kekayaan di antara individu-individu

2. suatu panduan bagi kebijakan dividen dan retensi perusahaan

3. panduan umum investasi dan pengambilan keputusan

4. suatu sarana prediktif yang membantu dalam meramalkan laba dan peristiwa-peristiwa ekonomi di masa depan

5. suatu alat ukur efisiensi yang menjadi ukuran baik dari keahlian kepengurusan manajemen atas sumber daya entitas maupun efisiensinya dalam menyelenggarakan urusan-urusan perusahaan 


\section{Manajemen Laba}

Manajemen laba menurut Achmad Solechan (2009) merupakan hal diperhatikan karena melibatkan potensi pelanggaran, kejahatan dan konflik yang dibuat pihak manajemen perusahaan dalam rangka menarik investor.

Terdapat beberapa motivasi yang mendorong manajer melakukan manajemen laba seperti yang diungkapkan oleh Scott dalam Ayudia Sokarina (2006):

1. Motivasi bonus

Manajer mempunyai informasi inside atas laba bersih perusahaan sebelum melakukan manajemen laba. Manajemen secara oportunistik akan mengelola laba bersih untuk memaksimalkan bonus mereka.

2. Motivasi perjanjian utang

Motivasi perjanjian utang menimbulkan adanya indikasi manajemen yang berdasarkan pada karakteristik bonus shemes, atau pun dapat timbul berdasarkan kontrak pinjaman jangka panjang.

3. Motivasi Politik

Motivasi politik terkait dengan ukuran perusahaan. Perusahaan dengan industri strategis seperti perusahaan minyak dan gas, atau perusahaan yang bersifat monopoli atau semi monopoli seperti perusahaan penerbangan diduga berkaitan dengan kemungkinan melakukan manajemen laba untuk mengurangi biaya politik.

4. Motivasi Pajak

Motivasi lain manajemen laba adalah pajak. Hal ini muncul karena kebijakan pajak cenderung untuk membebankan kebijakan akuntansi untuk keperluan perhitungan pajak pendapatan, yang pada akhirnya mengurangi ruang gerak perusahaan.

\section{Hubungan Laba dengan Return} Saham

Pada umumnya para investor mengharapkan dapat memperoleh pengembalian investasi (return) pada tingkat tertentu dari dana yang mereka keluarkan. Hal ini disebabkan seringnya investor dihadapkan dengan berbagai resiko dan ketidakpastian yang sulit diprediksi dalam berinvestasi. Tidak jarang investor yang tidak memperoleh tingkat pengembalian (return) yang sesuai dengan harapannya menjadi kecewa bahkan menjual saham tersebut ketika harga turun. Oleh karena itu, setiap 
perusahaan harus memberikan informasi akuntansi, khususnya laba, yang dipublikasikan sehingga masyarakat dapat mengetahui reaksi pasar terhadap informasi tersebut. Pasar yang mengetahui dan meyakini bahwa laba yang dilaporkan oleh perusahaan memiliki kandungan informasi, maka akan tercermin pada harga saham perusahaan tersebut (Boediono, 2005).

Dengan adanya beberapa metode penyusunan laporan keuangan, maka akan berpengaruh terhadap laba. Metode penyusutan saldo menurun akan menghasilkan hasil laba yang berbeda dengan metode garis lurus. Praktik seperti ini menurut Boediono (2005) dapat memberikan dampak terhadap kualitas laba yang dilaporkan sehingga kualitas laba dapat diindikasikan sebagai kemampuan informasi laba memberikan respon kepada pasar. Dengan kata lain, menurut Boediono, laba yang dilaporkan memiliki kekuatan respon (power of response). Kuatnya reaksi pasar terhadap informasi laba yang tercermin dari tingginya earnings response coefficients (ERC), menunjukkan laba yang dilaporkan berkualitas (Boediono, 2005). Scott, Cho dan Jung dalam Boediono
(2005) menyatakan bahwa ERC mengukur seberapa besar return saham dalam merespon angka laba yang dilaporkan oleh perusahaan yang mengeluarkan sekuritas tersebut.

\section{Review Penelitian Relevan}

Penelitian terdahulu yang dapat mendukung penelitian ini adalah Lev dan Nissim (2004) dalam penelitiannya yang berjudul "Taxable Income, Future Earnings, and Equity Values". Penelitian ini menyimpulkan bahwa book-tax differences berpengaruh positif terhadap return saham baik sebelum dan sesudah implementasi Statement of Financial Accounting Standards (SFAS).

Desai dan Dharmapala (2006) yang berjudul "Corporate Tax Avoidance and High-Powered Incentives". Penelitian ini menyimpulkan bahwa di antara penghindaran pajak dan insentif manajemen (manajemen laba) terdapat tax sheltering dan diversi manajerial. Penghindaran pajak untuk manajemen laba ini mengakibatkan laporan keuangan tidak mencerminkan keadaan sesungguhnya karena menimbulkan adanya perbedaan laba akuntansi dan laba pajak (book-tax gap). 
Semakin besar perbedaan itu, maka berpengaruh negatif terhadap abnormal return.

Pramitasari (2009) dalam penelitiannya yang berjudul "Analisis Book Tax Differences Terhadap Persistensi Laba dan Laba Akrual Sebagai Variabel Moderating Pada Perusahaan Yang Terdaftar di Bursa Efek Indonesia". Penelitian ini menyimpulkan bahwa book-tax differences baik positif maupun negatif tidak berpengaruh terhadap rendahnya persistensi laba dan yang berhubungan dengan komponen laba akrual tidak menyebabkan rendahnya persistensi laba baik untuk perusahaan bank, manufaktur dan non manufaktur. Penelitian ini menggunakan perbedaan temporer dalam analisis utama karena perbedaan temporer dapat menimbulkan jumlah pajak yang dapat ditambahkan atau dikurangkan di masa depan yang berhubungan dengan proses akrual.

Damayanti (2008) dalam penelitiannya yang berjudul "Perbandingan Akrual dan Pajak Tangguhan dalam Pengujian Aliran Kas Masa Datang dan Return Saham". Penelitian ini dilakukan pada 40 perusahaan manufaktur yang terdaftar di BEI periode 2000-
2004. Penelitian ini dengan model regresi yang menyimpulkan bahwa pajak tangguhan lebih memberikan ketepatan yang lebih tinggi dibandingkan akrual dalam memprediksi aliran kas dari aktivitas operasi perusahaan masa datang. Penelitian ini juga memberikan hasil bahwa pajak tangguhan lebih bermanfaat dibanding akrual dalam pengaruhnya terhadap return saham.

Tanusdjaja (2006) dalam penelitiannya yang berjudul "Hubungan Pajak Tangguhan dengan Harga Saham, Profitabilitas Masa Depan dan Aktivitas Manajemen Laba". Penelitian ini memberikan hasil bahwa variabel aktiva pajak tangguhan (DTA) dan komponen DTA yang berasal dari saldo rugi fiskal berhubungan positif dengan harga saham. Variabel penelitian lainnya seperti kewajiban pajak tangguhan (DTL) dan komponen pajak tangguhan yang berasal dari depresiasi dan penyiishan penilaian tidak terbukti memiliki pengaruh atau hubungan dengan harga saham.

Sasongko dan Wulandari (2005) dalam penelitiannya yang berjudul "Pengaruh EVA dan RasioRasio Profitabilitas Terhadap Harga Saham". Penelitian ini dilakukan 
pada 45 perusahaan manufaktur di BEI pada tahun 2001-2002. Berdasarkan hasil pengujian model regresi berganda, disimpulkan bahwa hanya EPS yang berpengaruh terhadap harga saham sedangkan return on assets, return on equity, return on sale, basic earning power dan economic value added tidak berpengaruh terhadap harga saham.

Mukhtaruddin dan Romalo (2007) dalam penelitiannya yang berjudul "Pengaruh Return On Assets (ROA), Return On Equity (ROE), Return On Investment (ROI), Debt To Equity Ratio (DER) dan Book Value (BV) Per Share Terhadap Harga Saham Properti di BEJ". Berdasarkan hasil pengujian model regresi linear berganda, disimpulkan bahwa ROA, ROE, ROI, DER dan BV secara bersama-sama mempengaruhi harga saham properti. Secara parsial disimpulkan bahwa ROA, ROE, ROI dan DER tidak mempunyai pengaruh terhadap harga saham. Namun, variabel BV secara parsial menunjukkan pengaruh terhadap harga saham perusahaan properti di BEJ.

$\begin{array}{ccr}\begin{array}{c}\text { Stella } \\ \text { penelitiannya }\end{array} & \text { yang } & \begin{array}{r}\text { dalam } \\ \text { berjudul }\end{array} \\ \text { "Pengaruh Price } & \text { To Earnings Ratio, }\end{array}$

Debt To Equity Ratio, Return on Asset dan Price To Book Value Terhadap Harga Pasar Saham". Penelitiannya menyimpulkan bahwa Price to Earnings Ratio berpengaruh positif signifikan terhadap harga saham, Debt To Equtiy Ratio dan Price To Book Value berpengaruh negatif terhadap harga saham sedangkan ROA tidak berpengaruh terhadap harga saham.

Syauta dan Widjaja (2009) dalam penelitiannya yang berjudul "Analisis Pengaruh Rasio ROA, LDR, NIM dan NPL Terhadap Abnormal Return Saham Perbankan di Indonesia Pada Periode Sekitar Pengumuman Subprime Mortgage". Berdasarkan hasil pengujian regresi linear berganda, rasio perbankan ROA, LDR , NIM dan NPL secara simultan mempunyai pengaruh terhadap cumulative abnormal return. Rasio ROA dan NPL memiliki pengaruh terhadap gejolak return saham perbankan. Sedangkan rasio LDR dan NIM tidak memiliki pengaruh terhadap gejolak return saham perbankan. 


\section{Kerangka Pemikiran}

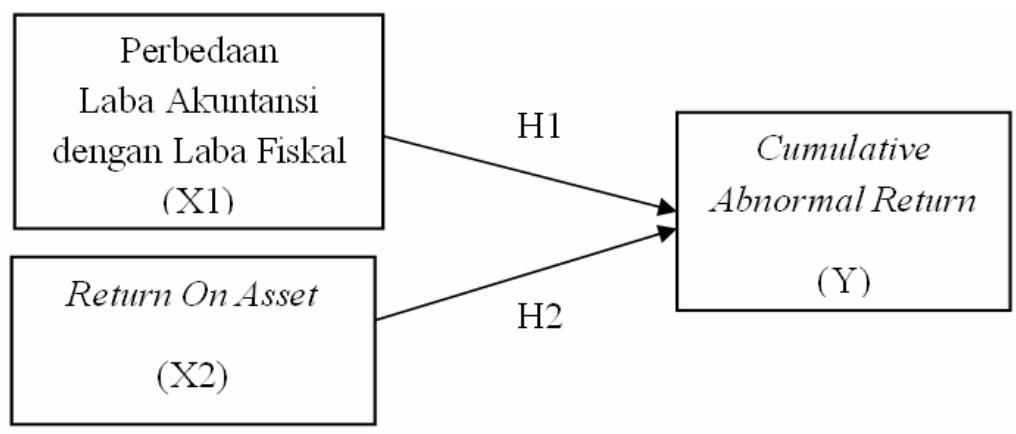

Gambar 2.1

Kerangka Pemikiran

Dalam penelitian ini, variabel independen yang digunakan adalah perbedaan laba akuntansi dan laba fiskal serta Return On Asset. Sedangkan variabel dependen yang digunakan adalah cumulative abnormal return. Semakin besar perbedaan laba akuntansi dan laba fiskal mengidentifikasi bahwa laporan keuangan tersebut sulit untuk dipercaya karena adanya manajemen laba. Manajemen laba yang semakin besar menyebabkan semakin rendah kualitas laba. Semakin rendah kualitas laba, harga saham akan menurun. Harga saham yang semakin menurun akan mengakibatkan return saham yang menurun juga. Apabila return saham menurun, maka abnormal return juga menurun.

Return on Assets (ROA) yang meningkat menunjukkan kinerja perusahaan juga meningkat. Kinerja perusahaan yang baik, akan membuat harga saham perusahaan tersebut meningkat. Harga saham yang meningkat akan berpengaruh terhadap meningkatnya total return yang diperoleh investor. Apabila return saham meningkat, maka abnormal return juga meningkat.

\section{Hipotesis}

Hipotesis penelitian ini adalah sebagai berikut:

$\mathrm{H} 1$ = perbedaan laba akuntansi dan laba fiskal memiliki pengaruh terhadap cumulative abnormal return

$\mathrm{H} 2=$ Return on Assets memiliki pengaruh terhadap cumulative abnormal return 


\section{METODOLOGI PENELITIAN}

Objek penelitian yang digunakan dalam penelitian ini adalah perusahaan manufaktur yang terdaftar di BEI tahun 2009.

Penelitian ini menggunakan metode regresi linear berganda. Metode ini dipilih karena sesuai dengan tujuan penelitian yang ingin dicapai, yaitu ingin mengetahui pengaruh variabel bebas (Perbedaan Laba Akuntansi dan Laba Fiskal dan ROA) yang diberi simbol masing-masing $\mathrm{X} 1$ dan $\mathrm{X} 2$ yang mempengaruhi dengan variabel terikat (cumulative abnormal return) yang dipengaruhi dan diberi simbol $\mathrm{Y}$.

Menurut Agoes dan Trisnawati (2008) perbedaan antara laba akuntansi dan laba fiskal tersebut dapat dikelompokkan menjadi 2 yaitu beda tetap dan beda sementara. Perbedaan laba akuntansi dan laba fiskal adalah selisih antara laba akuntansi dan laba fiskal.

ROA merupakan rasio keuangan yang menunjukkan kemampuan perusahaan menghasilkan laba dari aktiva yang dipergunakan (Hartono dan Sihotang, 2006).

ROA $=\quad$ laba bersih setelah pajak

total aktiva

Abnormal return adalah selisih antara return aktual dan return yang diharapkan. Cumulative abnormal return merupakan kumulatif harian abnormal return. Harga saham harian yang dipakai adalah closing price. Dalam penelitian ini menggunakan periode 1 tahun yaitu selama tahun 2009. Pengukuran abnormal return dalam penelitian ini menggunakan market adjusted model.

\section{HASIL PENELITIAN \\ Deskripsi Objek Penelitian}

Objek penelitian yang digunakan dalam penelitian ini adalah perusahaan manufaktur yang terdaftar di BEI tahun 2009 yang jumlahnya 140 perusahaan. Dari 140 perusahaan tersebut, untuk menentukan sampel dalam penelitian ini ditentukan secara purposive sampling dengan kriteria yang ditentukan sebagai berikut: 
Tabel 4.1

Penentuan Sampel dengan Kriteria

\begin{tabular}{|l|l|}
\hline Keterangan & Jumlah \\
\hline Perusahaan Manufaktur (2009) & 140 \\
\hline Perusahaan dalam keadaan rugi & 37 \\
\hline $\begin{array}{l}\text { Perusahaan memiliki hari perdagangan saham kurang dari 201 } \\
\text { hari selama tahun 2009 }\end{array}$ & 17 \\
\hline Perusahaan menyajikan laporan keuangan tidak dalam rupiah & 2 \\
\hline Laporan keuangan tidak tersedia di BEI & 7 \\
\hline Jumlah Sampel & 77 \\
\hline
\end{tabular}

Sumber: Data sekunder diolah peneliti, 2011

Berdasarkan tabel di atas, diperoleh sampel penelitian sebanyak 77 perusahaan.

\section{Analisis Statistik Deskriptif}

Analisis statistik deskriptif memberikan gambaran data tentang jumlah data, minimum, maksimum, mean dan standar deviasi (Priyatno, 2010:12). Variabel statistik deskriptif adalah perbedaan laba akuntansi dan laba fiskal, Return on Assets (ROA) dan Cumulative Abnormal Return (CAR) disajikan dalam lampiran.

Variabel yang digunakan dalam penelitian ini meliputi variabel independen dan variabel dependen. Variabel independen terdiri atas perbedaan antara laba akuntansi dan laba fiskal serta ROA. Sedangkan variabel dependennya adalah Cumulative Abnormal Return (CAR).

1. Perbedaan Laba Akuntansi dan Laba Fiskal (Book-Tax Differences)

Berdasarkan data yang dikumpul, perusahaan yang memiliki BTD tertinggi adalah PT Primaindo Asia Infrastructure Tbk sebesar 0.05702 . Sedangkan data terkecilnya sebesar -0.13808 pada PT Astra Otoparts Tbk. Nilai rata-rata 0.0013808 dengan standar deviasi 0.2662054 . Nilai standar deviasi yang lebih besar dari nilai rata-ratanya menunjukkan bahwa BTD untuk perusahaan yang menjadi sampel memiliki perbedaan yang relatif besar. Nilai deviasi yang besar menunjukkan adanya nilai-nilai 
ekstrim baik yang tinggi maupun yang rendah (Suharyadi dan Purwanto, 2003:112).

2. Return on Assets (ROA)

Berdasarkan data yang dikumpul, perusahaan yang memiliki ROA tertinggi adalah PT Unilever Indonesia Tbk sebesar 0.40669. Sedangkan data terkecilnya sebesar 0.00478 pada PT Kabelindo Murni Tbk. Untuk perhitungan selanjutnya diperoleh rata-rata ROA sebesar 0.0956681 dengan standar deviasi 0.08670395 . Nilai standar deviasi yang lebih kecil dibanding nilai rata-rata menunjukkan bahwa ROA setiap perusahaan yang menjadi sampel memiliki kesamaan (Suharyadi dan Purwanto, 2003:112).

3. Cumulative Abnormal Return (CAR)

Berdasarkan data yang dikumpul, perusahaan yang memiliki CAR tertinggi adalah PT Bentoel International Investama Tbk sebesar 5.86491. Sedangkan data terkecilnya sebesar -0.78983 pada PT Arwana Citra Mulia Tbk. Untuk perhitungan selanjutnya diperoleh rata-rata
CAR sebesar 0.6799931 dengan standar deviasi 1.09201597. Nilai standar deviasi CAR lebih besar dibandingkan rataratanya menunjukkan bahwa perusahaan-perusahaan yang menjadi sampel memiliki perbedaan CAR yang relatif besar. Nilai deviasi yang besar menunjukkan adanya nilai-nilai ekstrim baik yang tinggi maupun yang rendah (Suharyadi dan Purwanto, 2003:112).

\section{Uji Asumsi Klasik}

1. Uji Normalitas

Uji normalitas bertujuan untuk menguji apakah dalam model regresi, variabel pengganggu atau residual memiliki distribusi normal. Pada penelitian ini, pengujian distribusi normal dilakukan dengan metode parametrik, yaitu uji Lilliefors dengan melihat nilai pada Kolmogrov-Smirnov. Data dinyatakan berdistribusi normal jika signifikansi lebih besar dari 0.05 . Hasil uji normalitas dapat dilihat pada lampiran. Nilai signifikansi variabel $B T D=0.2$, $\mathrm{ROA}=0.074$ dan $\mathrm{CAR}=0.2$. maupun indepedennya di atas 0.05. Oleh karena semua 
variabel memiliki nilai signifikansi > 0.05, maka dapat disimpulkan bahwa data berdistribusi normal.

2. Uji Multikolinearitas

Uji multikolinearitas digunakan untuk menguji apakah model regresi ditemukan adanya korelasi antar variabel bebas (independen). Salah satu cara untuk mengetahui ada tidaknya multikolinearitas pada suatu model adalah dengan melihat nilai yang dipakai untuk menandai adanya faktor multikolinearitas. Nilai yang dipakai adalah nilai nilai tolerance $\leq 0.10$ atau sama dengan nilai VIF $\geq 10$. Hasil uji multikolinearitas dapat dilihat pada lampiran. Nilai tolerance $=$ 0.998 dan VIF $=1.002$. Oleh karena itu, dapat disimpulkan bahwa dalam penelitian ini tidak terjadi multikolinearitas dalam model regresinya.

3. Uji Autokorelasi

Uji autokorelasi digunakan untuk mengetahui ada atau tidaknya korelasi yang terjadi antara residual pada satu pengamatan dengan pengamatan lain pada model regresi. Salah satu cara untuk mengetahui ada tidaknya autokorelasi pada model regresi adalah dengan melakukan uji durbin-watson (DW). Hasil uji autokorelasi dapat dilihat pada lampiran. Untuk taraf signifikansi $5 \%$ dengan $\mathrm{k}=2$ dan $\mathrm{n}=32$, diperoleh $\mathrm{dL}=1.3093$ dan $\mathrm{dU}=1$.5736. Dengan 4-dU $=2.4264,4-\mathrm{dL}=2.6907 \mathrm{dan}$ $\mathrm{dW}=1.709$, maka $\mathrm{dU}<\mathrm{dW} \leq$ 4 - dU. Oleh karena itu, dapat disimpulkan bahwa dalam penelitian ini tidak terjadi autokorelasi dalam model regresinya.

4. Uji Heteroskedastisitas

Uji heteroskedastisitas bertujuan menguji apakah dalam model regresi terjadi ketidaksamaan variance dari residual atau pengamatan ke pengamatan yang lain. Salah satu cara untuk mengetahui ada tidaknya heteroskedastisitas pada model regresi adalah dengan melakukan uji Park. Hasil uji heteroskedastisitas dapat dilihat pada lampiran. Dari tabel dapat dilihat bahwa nilai signifikansi $>0.05$ yaitu variabel $B T D=0.261$ dan $\mathrm{ROA}$ $=0.361$. Oleh karena itu, dapat disimpulkan bahwa dalam penelitian ini tidak terjadi 
heteroskedastisitas dalam model regresinya.

\section{Analisis Regresi Linear Berganda}

Analisis regresi linear berganda adalah hubungan secara linear antara dua atau lebih variabel independen dengan variabel dependen (Priyatno, 2010: 61). Analisis regresi linear berganda dalam penelitian ini sebagai berikut:

$$
Y=0.602+77.833 X_{1}-
$$

$4.171 X_{2}$

\section{Pengujian hipotesis}

\section{Pengujian Hipotesis Pertama}

Hipotesis nol pertama dalam penelitian ini adalah tidak terdapat pengaruh antara Book-Tax Differences dengan CAR. Berdasarkan hasil uji $t$, diperoleh tingkat signifikansi 0.010 yang berarti lebih kecil daripada tingkat signifikansi 5\% (0.05). Hal ini berarti bahwa secara parsial variabel Book-Tax Differences berpengaruh secara signifikan terhadap CAR pada perusahaan manufaktur yang terdaftar di BEI pada tahun 2009. Karena nilai t-hitung positif $2.742>$ nilai t-tabel 2.045, maka hipotesis nol pertama $\left(\mathrm{H}_{01}\right)$ yang menyatakan bahwa BTD tidak berpengaruh terhadap CAR tidak terbukti. Oleh karena itu, hipotesis pertama $\left(\mathbf{H}_{\mathbf{1}}\right)$ yang menyatakan bahwa BTD berpengaruh terhadap CAR didukung.

\section{Pengujian Hipotesis Kedua}

Hipotesis nol kedua dalam penelitian ini adalah tidak terdapat pengaruh antara ROA dengan CAR. Berdasarkan hasil uji $t$, diperoleh tingkat signifikansi 0.221 yang berarti lebih besar daripada tingkat signifikansi 5\% (0.05). Hal ini berarti bahwa secara parsial variabel ROA tidak berpengaruh secara signifikan terhadap CAR pada perusahaan manufaktur yang terdaftar di BEI pada tahun 2009. Karena nilai t-hitung $-1.252<$ nilai t-tabel 2.045, maka hipotesis nol kedua $\left(\mathrm{H}_{02}\right)$ yang menyatakan bahwa ROA tidak berpengaruh terhadap CAR diterima. Oleh karena itu, hipotesis pertama $\left(\mathbf{H}_{2}\right)$ yang menyatakan bahwa ROA berpengaruh terhadap CAR tidak didukung.

Pengaruh Perbedaan Laba Akuntansi dan Laba Fiskal Terhadap Cumulative Abnormal Return (CAR)

Semakin besar perbedaan laba akuntansi dan laba fiskal, maka laporan keuangan tersebut sulit 
untuk dipercaya karena semakin besar manajemen laba. Manajemen laba yang semakin besar menyebabkan semakin rendah kualitas laba. Semakin rendah kualitas laba, harga saham akan menurun. Harga saham yang semakin menurun akan mengakibatkan return saham yang menurun juga. Apabila return saham menurun, maka abnormal return juga menurun.

Dalam pengujian hipotesis dengan uji $t$, didapatkan nilai $t-$ hitung sebesar 2.742 pada tingkat signifikansi $\quad 0,010 \quad$ yang menunjukkan bahwa hipotesis nol pertama $\left(\mathrm{H}_{01}\right)$ yang menyatakan bahwa BTD tidak berpengaruh terhadap CAR tidak terbukti. Oleh karena itu, BTD berpengaruh terhadap CAR perusahaan manufaktur yang terdaftar di Bursa Efek Indonesia (BEI) pada periode tahun 2009. Hasil penelitian ini sejalan dengan penelitian Lev dan Nissim (2004) bahwa book-tax differences berpengaruh positif terhadap return saham baik sebelum dan sesudah implementasi Statement of Financial Accounting Standards (SFAS). Selain itu, penelitian Tanusdjaja (2006) menyimpulkan bahwa variabel aktiva pajak tangguhan (DTA) dan komponen DTA yang berasal dari saldo rugi fiskal berhubungan positif dengan harga saham.

Hasil penelitian ini berpengaruh positif antara BTD dengan CAR dapat disebabkan karena perbedaan tersebut dianggap transaksi yang wajar oleh para investor. Seperti dalam transaksi penjualan, Sebelum memberikan penjualan secara kredit, seharusnya perusahaan yang wajar memperhatikan kinerja perusahaan yang terkait dengan kemampuan dalam melunasi hutang pembeliannya nanti. Tetapi terkadang, perusahaan yang agresif melakukan pernjualan kredit tersebut karena hanya untuk meningkatkan volume penjualan. Pada awalnya, piutang tersebut pada laba komersial dicatat sebagai pendapatan namun tidak dicatat dalam laporan laba rugi fiskal. Kemudian dapat menjadi beban piutang tak tertagih pada laporan komersial. Dengan adanya beban tersebut, akan mengurangi laba komersial yang mempengaruhi laba fiskal. Namun, cenderung perusahaan sebelum melakukan transaksi penjualannya secara kredit dengan memperhatikan kinerja dan kemampuan pembelinya dalam pembayarannya. Jadi, transaksi seperti inilah yang dipandang wajar 
oleh investor. Adanya perbedaan laba akuntansi dan laba fiskal yang wajar ini dapat dilihat dari piutang tak tertagih tahun 2008 yang sebagian besar telah menjadi kas pada tahun 2009. Oleh karena itu, kewajaran dari perbedaan ini tidak mengurangi minat investor dalam membeli saham. Bahkan laporan keuangan yang dinilai masyarakat bersifat wajar cenderung membuat masyarakat lebih tertarik untuk menanamkan sahamnya. Oleh karena itu, CAR tetap dapat mengalami kenaikan.

\section{Pengaruh ROA Terhadap Cumulative Abnormal Return (CAR)}

Secara teori, semakin besar nilai ROA dapat diartikan bahwa perusahaan tersebut semakin mampu untuk menghasilkan laba dari aktivanya. Return on Assets (ROA) yang meningkat menunjukkan kinerja perusahaan juga meningkat. Kinerja perusahaan yang baik, akan membuat harga saham perusahaan tersebut meningkat. Harga saham yang meningkat akan berpengaruh terhadap meningkatnya total return yang diperoleh investor. Apabila return saham meningkat, maka abnormal return juga meningkat.
Dalam pengujian hipotesis dengan uji $t$, didapatkan nilai $t$ hitung sebesar -1.252 pada tingkat signifikansi $\quad 0,221 \quad$ yang menunjukkan bahwa hipotesis nol kedua $\left(\mathrm{H}_{02}\right)$ bahwa ROA tidak berpengaruh terhadap CAR diterima. Oleh karena itu, ROA tidak berpengaruh terhadap perusahaan manufaktur yang terdaftar di Bursa Efek Indonesia (BEI) pada periode tahun 2009. Hasil penelitian ini sejalan dengan penelitian Sasongko dan Wulandari (2005), Mukhtaruddin dan Romalo (2007) serta Stella (2009) dalam penelitiannya yang menyimpulkan bahwa return on assets tidak berpengaruh terhadap harga saham. Namun, penelitian ini berbeda dengan penelitian Syauta dan Widjaja (2009) dalam penelitiannya juga menyimpulkan bahwa rasio ROA memiliki pengaruh terhadap gejolak return saham perbankan.

ROA yang tidak berpengaruh terhadap harga saham dalam penelitian ini dapat disebabkan karena sekalipun kinerja keuangan perusahaan secara rasio dianggap baik dan perusahaan tersebut cukup besar di mata investor, namun dengan harga saham yang cukup tinggi ataupun ketika harga saham 
tersebut mengalami kenaikan membuat investor menjadi kurang tertarik. Dari data yang terlampir, dapat dilihat bahwa sekalipun perusahaan dengan total aset yang tinggi tidak selalu berarti memiliki nilai CAR yang tinggi. Demikian pula dengan perusahaan yang memiliki total aset yang rendah tidak selalu berarti memiliki nilai CAR yang rendah pula. Seperti PT Astra International Tbk dengan nilai total aset tertinggi mencapai $\mathrm{Rp}$ 88.938.000.000.000,- namun memiliki nilai CAR yang lebih rendah dari PT Betonjaya Manunggal yang nilai total asetnya $\mathrm{Rp}$ 69.783.877.404,-. Hal ini dapat disebabkan karena beberapa perusahaan yang total asetnya kecil namun dipandang investor mempunyai kesempatan yang lebih besar untuk menaikkan harga sahamnya dibandingkan perusahaan yang total asetnya besar. Selain itu, perusahaan besar cenderung memiliki harga saham yang telah cukup tinggi. Jadi, jika perusahaan besar menaikkan harga saham dengan kenaikan yang besar memiliki kemungkinan yang kecil. Hal inilah yang dapat menyebabkan ROA menjadi kurang berpengaruh terhadap harga saham.

\section{KESIMPULAN DAN SARAN Kesimpulan}

Penelitian ini bertujuan untuk mengetahui apakah ada pengaruh antara book-tax differences dan ROA terhadap cumulative abnormal return pada perusahaan manufaktur yang terdaftar di BEI pada tahun 2009. Penelitian ini menggunakan model regresi linear berganda yang memberikan hasil bahwa book-tax differences berpengaruh terhadap cumulative abnormal return. Pengaruh yang positif ini dapat disebabkan karena adanya transaksi yang wajar. Hasil penelitian ini sejalan dengan penelitian Lev dan Nissim (2004) bahwa book-tax differences berpengaruh positif terhadap return saham.

Return on Assets (ROA) tidak terbukti berpengaruh terhadap CAR pada perusahaan manufaktur yang terdaftar di BEI tahun 2009. Hal ini dapat disebabkan karena beberapa perusahaan yang total asetnya kecil namun dipandang investor mempunyai kesempatan yang lebih besar untuk menaikkan harga sahamnya dibandingkan perusahaan yang total asetnya besar. Hasil penelitian ini sejalan dengan penelitian Sasongko dan Wulandari (2005) Mukhtaruddin dan Romalo (2007) serta Stella (2009) dalam 
penelitiannya yang menyimpulkan bahwa return on assets tidak berpengaruh terhadap harga saham.

\section{Implikasi}

Penelitian ini mencoba melihat pengaruh antara perbedaan laba akuntansi dan laba fiskal, Return on Assets (ROA) dan Cumulative Abnormal Return (CAR) pada perusahaan manufaktur yang terdaftar di BEI. Berdasarkan hasil penelitian ini, terbukti bahwa perbedaan laba akuntansi dan laba fiskal berpengaruh signifikan terhadap nilai CAR. Sedangkan ROA tidak berpengaruh signifikan terhadap CAR. Secara teoritis, hasil penelitian ini berimplikasi pada pengembangan akuntansi keuangan yang berkaitan dengan teori efisiensi pasar karena dari hasil penelitian ini menunjukkan adanya pengaruh positif perbedaan laba akuntansi dan laba fiskal dengan CAR. Selain secara teoritis, dalam hal praktis hasil penelitian ini berimplikasi pada perusahaan manufaktur agar lebih memperhatikan selisih dari laba akuntansi dan laba fiskal yang dapat mempengaruhi minat investor terhadap saham perusahaan

\section{Keterbatasan Penelitian}

Penelitian ini memiliki beberapa keterbatasan, antara lain:

1. Jumlah sampel dilakukan dengan mensyaratkan kriteriakriteria tertentu, yaitu dengan membatasi kriteria sampel hanya perusahaan manufaktur. Oleh karena itu, hasil penelitian ini tidak dapat digeneralisasi untuk perusahaan di luar manufaktur.

2. Pengujian penelitian ini menghasilkan nilai Adjusted $\mathrm{R}^{2}$ yang rendah. Rendahnya nilai Adjusted $\mathrm{R}^{2}$ karena masih banyak variasi variabel independen lainnya yang telah dilakukan peneliti sebelumnya yang dapat mempengaruhi CAR

\section{Saran}

Berdasarkan hasil penelitian , saran yang dapt diberikan antara lain:

1. Bagi investor maupun calon investor, untuk memilih saham perusahaan yang menguntungkan dalam jangka panjang sebaiknya tidak hanya memperhatikan kinerja perusahaan secara rasio keuangan saja tetapi juga laporan keuangan secara keseluruhan 
2. Bagi perusahaan, agar perusahaan lebih memperhatikan selisih dari laba akuntansi dan laba fiskal serta kenaikan harga saham karena dapat mempengaruhi minat investor terhadap saham perusahaan

3. Bagi peneliti selanjutnya, dapat menambahkan sampel perusahaan dengan menggunakan semua jenis perusahaan yang telah terdaftar di BEI

\section{DAFTAR PUSTAKA}

Achmad Solechan, 2009. "Pengaruh Manajemen Laba dan Earning Terhadap Return Saham". Tesis. Pascasarjana UNDIP, Semarang.

Adler Haymans Manurung, 2009. "Berinvestasi dan Perlindungan Investor di Pasar Modal". Perbanas Quarterly Review, vol. 2, no. 1, h. 1433.

Agoes, Sukrisno dan Estralita Trisnawati. Akuntansi

Perpajakan. Jakarta: Salemba Empat, 2008.

Agung Suaryana, 2008. "Pengaruh Konservatisme Laba Terhadap Koefisien Respons Laba".
Jurnal Akuntansi dan Bisnis, vol. 3, no. 1 .

Ayudia Sokarina, 2006. "Pengaruh Manajemen Laba Terhadap Return Saham". Jurnal Riset Akuntansi Aksioma, vol. 5, no.2, h. 1-15.

Bety Pramitasari, 2009. "Analisis Book Tax Differences Terhadap Persistensi Laba dan Laba Akrual Sebagai Variabel Moderating Pada Perusahaan Yang Terdaftar di Bursa Efek Indonesia". Jurnal Akuntansi dan Investasi, vol. X, no.1. h. 45-56.

Darmadji, Tjiptono dan Hendy M. Fakhruddin, 2001. Pasar Modal di Indonesia: Pendekatan Tanya Jawab. Jakarta: Salemba Empat.

Desai, Mihir A. dan Dhammika Dharmapala, 2006. "Corporate Tax Avoidance and HighPowered Incentivies". Journal of Financial Economics 79. p. 145-179.

Duwi Priyatno, 2010. Paham Analisa Statistik Data Dengan SPSS. Yogyakarta: MediaKom.

Gideon Boediono, 2005. "Kualitas Laba: Studi Pengaruh Mekanisme Corporate Governance dan Dampak Manajemen Laba Dengan 
Menggunanakan Analisis

Jalur". SNA, Vol. VIII. h. 172-

194.

Hartono dan Raymundus Parulian

Sihotang, 2008. "Analisis

Hubungan Profitabilitas

Dengan Pergerakan Harga

Saham Pada Sektor Usaha

Perbankan di Bursa Efek

Indonesia". Journal of Applied

Finance and Accounting, no. 2, h. 51-66.

Hendang Tanusdjaja, 2006.

"Hubungan Pajak Tangguhan

dengan Harga Saham,

Profitabilitas Masa Depan dan

Aktivitas Manajemen Laba."

Disertasi. Pascasarjana FE UI,

Depok.

Ikatan Akuntan Indonesia, 2010.

PSAK No. 46 tentang Pajak

Penghasilan.

Imam Ghozali, 2009. Aplikasi

Analisis Multivariate dengan

Program SPSS. Semarang:

Badan Penerbit Universitas

Diponegoro.

Jogiyanto Hartono, 2009. Teori

Portofolio dan Analisis

Investasi. Yogyakarta: BPFE.

Katoppo, Aristides et al, 1997. Pasar

Modal Indonesia: Prospeksi

Lima Tahun Swastanisasi BEJ.

Jakarta: Pustaka Sinar

Harapan.
Lev, Baruch dan Doron Nissim, 2004. "Taxable Income, Future Earnings, and Equity Values". The Accounting Review. p. 1039-1074.

Michael Hendrawijaya Dj, 2009. "Analisis Perbandingan Harga Saham, Volume Perdagangan Saham dan Abnormal Return Saham Sebelum dan Sesudah Pemecahan Saham (studi pada perusahaan go public yang melakukan pemecahan saham antara tahun 20052008 di BEI)". Tesis Pascasarjana Universitas Diponegoro, Semarang.

Mukhtaruddin dan Desmoon King Romalo, 2007. "Pengaruh Return On Assets (ROA), Return On Equity (ROE), Return On Investment (ROI), Debt To Equity Ratio (DER) dan Book Value (BV) Per Share Terhadap Harga Saham Properti di BEJ". Jurnal Penelitian dan Pengembangan Akuntansi, vol. 1, no. 1, h. 6977.

Nur Hidayat, 2002. "Analisis Perbandingan Laporan Keuangan Fiskal vs Laporan Keuangan Komersial". Jurnal Perpajakan Indonesia, vol. 1, no. 10 , h. 32-35. 
Prastowo, Dwi dan Rifka Juliaty, 2008. Analisis Laporan Keuangan: konsep dan aplikasi. Yogyakarta: Sekolah Tinggi Ilmu Manajemen YKPN.

Riahi, Ahmed dan Belkaoui, 2007. Accounting Theory, terj. Ali Akbar Yulianto dan Krista. Jakarta: Salemba Empat.

Sasongko, Noer dan Nila Wulandari, 2006. "Pengaruh EVA dan Rasio-Rasio Profitabilitas Terhadap Harga Saham". Empirika, vol. 19, no. 1, p. 6480.

Stella, 2009. "Pengaruh Price to Earnings Ratio, Debt to Equity Ratio, Return on Asset dan Price to Book Value Terhadap Harga Pasar Saham". Jurnal Bisnis dan Akuntansi, no. 2, h. 97-106.
Suharyadi dan Purwanto, 2003. Statistika Untuk Ekonomi dan Keuangan Modern. Jakarta: Salemba Empat.

Syauta, Risky C dan Indra Widjaja, 2009. "Analisis Pengaruh Rasio ROA, LDR, NIM dan NPL Terhadap Abnormal Return Saham Perbankan di Indonesia Pada Periode Sekitar Pengumuman Subprime Mortgage". Journal of Applied Finance and Accounting, vol. 1, no. 2, p. 339-350.

Theresia Woro Damayanti, 2008. "Perbandingan Akrual dan Pajak Tangguhan dalam Pengujian Aliran Kas Masa Datang dan Return Saham". Jurnal Akuntansi, no. 3, h. 250-259. 